\title{
A Review of the Challenges of Air Pollution in Contemporary Nigerian and Global Environment
}

\author{
Dr. Sylvanus, Abila \\ Senior Lecturer and Former Head of Department, Private/Property Law, \\ Faculty of Laws Niger Delta University, Wilberforce Island, Bayelsa State, Nigeria
}

\begin{abstract}
This paper reviews the challenges of air or atmospheric pollution in contemporary Nigeria and the global environment. In achieving its aim, the paper examines specific sources of air pollution, the impacts or dangers posed by the phenomenon. A comparative review is also taken of air or atmospheric pollution in selected incidences in Nigeria and around the globe. This is followed by a conclusion and a set of recommendations. The paper adopts and admixture of the historical, comparative, the law and development and empirical approaches in appropriate cases.
\end{abstract}

Keywords: Review, Challenges, Air Pollution, Particulate Matter, Contemporary Nigeria, Global Environment. DOI: $10.7176 /$ CER/12-1-05

Publication date: January $31^{\text {st }} 2020$

\subsection{INTRODUCTION}

Air pollution is known to be as old as "the primitive man". It is axiomatic and very well settled and vindicated by "research findings catalogued below that "the early man polluted the air by throwing dusts into the air through digging or tilling and burning of fires in cooking and bush clearing". But, the type of air pollution we are experiencing, today, in Nigeria and many nations, the world over, is [traceable as being] a by-product of the industrial revolution. According to one strong view, "the industrial revolution is known to have brought in its train, smoke pollution of a kind never seen before then. It has air pollution laden with harmful particulates matter, noxious fumes and substances. This has increased in degrees and varieties in the march of nations towards progress which is ably aided by the advancement of nations in advanced technology.... (his position of things, is further aggravated by the fact that)... "we no longer walk or ride, whatever we rode in the past, to places. We drive vehicles public or private, go by train or air. The result of this is that while we make progress via efficient and fast systems of transportation we throw into the air more harmful pollutants. And because fossil fuel, that is, coal or petroleum which is thus consumed causes acid rain and produces "greenhouse effect"1 through carbon dioxide [which] is generated; ${ }^{2}$ it also produces incomplete combusting carbon monoxide which is a colourless and odourless but poisonous gas. ${ }^{3}$

Another source of air pollution is the use of electricity generating sets and all other engines or machines that are powered by fossil fuels in factories and homes which are abundant, in Nigeria and other parts of the world. It should be added that the mere burning of coal or oil produces sulphur oxide, a very dangerous pollutant responsible for the most recent air pollution hazards to man, plants and materials. ${ }^{4}$ Apart from combustion of fuel, the atmosphere is also known to be polluted via industrial processes such as blasting operations, smelting, manufacturing, welding, amongst, several other harmful particles, are introduced into the air. This source of air pollution is also abundant in Nigeria. Furthermore, these materials introduced, used and similar products introduced to the air, in the process of industrial operations are known to destroy the air quality. Available research evidence show that artificial gas, chemical and their compounds leak or spew into the air regularly are veritable sources of air pollution ${ }^{5}$. Most products, in addition to the ones named above, are known to contain toxic substances like mercury and lead which eventually end up in the air. Asbestos which cause cancer is not, also, only dangerous to the users or workers in industries but to society as a whole, whenever they get into the air. To the above, we must add that, air pollution caused by the use of pesticide sprays or chemicals and various fungicides used by farmers in various nations of the world. This, perhaps, explains, why the 1979 convention on long-range transboundary air described, pollution as: "the introduction of man directly or indirectly of substances or energy into the air resulting effects of such a nature as to endanger human health living resources and ecosystems ---- material property and impair or interfere with amenities and other legitimate uses of the environment." 6

\footnotetext{
${ }^{1}$ See The Former British Prime Minister, Mrs. Magret Thatcher, The Guardian, October 22, 1988, p. 11.

${ }^{2}$ Carbon dioxide per $\$ e$ is not dangerous because it is not easily raised to a toxic level by burning fossil fuel. Quoting from the pollution crisis supra note 11 at p. 235, it is dangerous "because of its absorptive effect on the transmission of heat radiated upward from the earth by the atmosphere. The more carbon dioxide, the less heat is passed back into space and the warmer the earth. Thus the term "greenhouse effect." See generally J.A. Omotola Environmental Laws, published by Faculty of Law University of Lagos 1990, pp.191-205. ${ }^{3}$ Ibid

${ }^{4}$ See Reltze Jr. op. cit. Chapter 3, p. 2, Grad op. cit. Chapter 3, p. 3, Cassell, op. cit.

${ }^{5} \mathrm{Ibid}$

${ }^{6}$ Article 1, See Environmental Law and Policy Edited by Simpson and Fagbohun and published in 1998 by Law Centre, Faculty of Law, Lagos
} 


\subsection{RECENT REPORTS OF THE WORLD HEALTH ORGANIZATION (WHO) ON THE SOURCES AND IMPACTS OF AIR POLLUTION}

According to a report reproduced by The Guardian ${ }^{l}$, the World Health Organization (WHO), has confirmed that an average of 4.2 million deaths occur every year as a result of exposure to outdoor air pollution, while 3.8 million deaths occur as a result of household exposure to smoke from dirty cooking stoves and firewood, $25 \%$ of all heart diseases and $43 \%$ of lung diseases and lung cancer deaths are attributable to air pollution. The World Health Organization (WHO), also stated that lower respiratory infections like pneumonia and bronchitis to have replaced AIDS as the leading cause of deaths in Africa in 2015. Respiratory infections, have also been ranked between meningitis and malaria as leading causes of death in Africa. ${ }^{2}$

It is, therefore, needless to re-emphasis the fact that air pollution is the release of pollutants into air which are detrimental to human health not only in Nigeria, Africa but the entire planet as a whole. The combined effects off outdoor and household air pollution are also estimated by the same report to cause about 7 million premature deaths every year. Research evidence also show further heavy human causalities leading to increased mortality from stroke, heart disease, chronic obstructive pulmonary disease, lung cancer and acute respiratory infections. Apart from damaging human and animal health, air pollution is known to cause damages to vegetation and materials on earth ${ }^{3}$ just as the continual generation of air pollutions contributes to the acidification of coastal waters which indirectly affects human and aquatic organisms. While all regions of the world are affected by air pollution, low-income cities are, known to be, most impacted. ${ }^{4}$

According to a recent air quality database collated by WHO, $97 \%$ of cities in low and middle income countries shows that more than 100,000 do not meet the WHO air quality guidelines in global human settlements. In the year 2016, for an example, the World Bank reported that $94 \%$ of the Nigerian population is exposed to air pollution levels that exceed WHO guidelines for with air pollution damages costing about $1 \%$ of Gross National Income. ${ }^{5}$

According to the Guardian Newspapers Nigeria, editorial, for example, "Onitsha, one of the biggest commercial cities in the Eastern part of Nigeria recorded 30 times more than the World Health Organization's recommended levels of PM10 (particulate matter). Studies on Nigeria, carried out by the now disbanded Federal Environmental Protection Agency, had earlier shown that a moderate to high concentration of pollutants such as carbon monoxide, sulphur dioxide, nitrogen oxides, organic acids, particulate matters and hydrocarbon in the atmosphere, majority of which come from automotive engines and industries"6 has being prevalent in Nigeria.

The aforementioned Guardian editorial further named factors contributing to air pollution in Nigeria, relying on Nigerian Liquefied Petroleum Gas Association reports to include the "heavy reliance on firewood for cooking; that 3 million households and about 100 million Nigerians still rely on firewood as source of energy for cooking, burning waste, dust emissions from very old cars, poisonous fumes from generators, as well as Industrial houses. The editorial, further discovered that over sixty million households make use of generators on a daily basis and thus exposing a huge population of Nigerians to generator fumes which are a mixture of toxic and environmentally unfriendly gases, including carbon monoxide. Diesel fuel used in trucks and buses have also being found to pose a major problem as diesel fuel contains high amounts of sulphur which is highly toxic as inhalation of sulphur --- aggravate illness in those with already weakened respiratory function, such as asthmatics. The findings of the paper further revealed that "Industrial enterprises and thermal power stations contribute substantially to the atmospheric pollution in Nigeria. The industrial sources of air pollution resulting from the activities of cement industries, petrochemical industries and petroleum refineries are also major sources of greenhouse gas emissions". ${ }^{7}$

Greenhouse gases are also a major challenge and a veritable source of air pollution in Nigeria, Africa and the world at large. All the above mentioned sources constitute a group of compounds that are able to trap heat in the atmosphere. It is important to note that trapping the earth's heat in the atmosphere, greenhouse gases lead to warmer temperatures and all the features of climate change which include rising sea levels, unusual floodings, extreme weather conditions, heat-related deaths, and increasing transmission of infectious diseases like lyme. ${ }^{8}$ Nigeria is currently battling with the changes of heavy floodings (as it was in the year 2012) and other incidences of climate changes.

\footnotetext{
State University, Pp.311-312

${ }^{1}$ The Guardian, Friday, June 22, 2018. Page 32. Environment Month: Can Nigeria address the increasing threats of air pollution?

${ }^{2}$ Ibid.

${ }^{3}$ Ibid.

${ }^{4}$ Ibid

${ }^{5}$ The Guardian, Wednesday, July 4, 2018, P. 16: Editorial

${ }^{6}$ Ibid.

${ }^{7}$ See Reltzer Jr. op. cit. Chapter 3, P. 2, Grad op. cit. Chapter 3, P. 3, Cassell, op cit.

${ }^{8} \mathrm{Ibid}$
} 


\subsection{A COMPARATIVE HISTORICAL/CURRENT SUMMARY OF AIR POLLUTION INCIDENCES IN LAGOS STATE, THE NIGER DELTA REGION OF NIGERIA AND SOME OTHER PARTS OF THE GLOBE ON RECORD}

There are recent recorded incidences and concerns over air pollution in Lagos State, the Niger Delta region of Nigeria and some other parts of the globe ${ }^{1}$ in requiring urgent attentions and interventions. According to The Guardian newspapers, for example, in Nigeria ${ }^{2}$ there are many incidences of sudden air pollution which are, not only injurious to the atmosphere (leading to) but also, for example, the deaths of human beings and livestock. In the year 1986, for example, Cameroun, a nation in Africa, experienced the loss of lives 17000 people and livestock following the emission of carbon dioxide gas, overnight, from Lake Nyos. It is necessary also refer to reports of the emissions noticed recently, at the Olusosun dumpsite in Lagos and the cases of "fires and thick cloud of black smoke over the entire skylines in Lagos" which brought about so much panic, in Lagos and "fear that those living around the said area in Lagos are (were) exposed to the danger of inhaling toxic fumes that could exacerbate respiratory track diseases and cause avoidable deaths. The odour from the said dumpsite alone (became) unbearable. It is unimaginable how people have survived in the area, certainly, not without developing some health conditions. A combination of stench and ----- toxic fumes expose people to potential health hazards. The explanation by the Lagos State Government that the emissions were a natural outcome of trapped gases escaping to cause combustion rather validates the fact that the emissions phenomenon are dangerous to human health and instrumental to climate change. It is to be observed, further that the first air major visible air pollution occurred in Lagos, Nigeria, on October 12, 2005, for instance, when the choking smog hanging over the city. "The incident lasted for over six hours. Anxiety was raised as to the cause of the overhanging thick blanket. That gave insight into the magnitude of pollution in the sprawling mega-city. Unfortunately, to date, no official or tangible scientific explanation has been offered on the incident. Environmentalists say it was "nature's red-light warning against the model of inefficient and blind development."3

The Guardian editorial referred above further made references to November 2013, when 25 students of Ogba Junior Secondary School in Ikeja, Lagos, (Nigeria) fainted after inhaling what was presumed to be poisonous fumes from a nearby industrial plant. Though, the school was promptly closed after the incident, it was re-opened shortly after without the Lagos State Government authorities establishing the exact nature of the fumes and the extent of damage it may have caused. The foregoing represents the tip of the iceberg. There are reasons to believe that several of such dangerous incidents, including those resulting in fatalities occur daily in Lagos State and other part of Nigeria. The issue of air pollution appears not to be taken seriously by the authorities in Nigeria. Regular air quality monitoring in and around Lagos, Nigeria, Africa and other part of the world need to make environmental assessment of at least 50 kinds of highly toxic gases that could prove fatal when inhaled in large quantities. These include bromine $\left(\mathrm{Br}_{2}\right)$, carbon monoxide $(\mathrm{CO})$, chlorine $\left(\mathrm{Cl}_{2}\right)$ and hydrogen sulphide $\left(\mathrm{H}_{2} \mathrm{~S}\right)$. Human contact with any of these toxic gases could manifest in suffocations, faintings, irritations of the eyes and skin leading to blisters because such extreme exposures could be fatal.

\subsection{AIR OR ATMOSPHERIC POLLUTION IN NIGER DELTA REGION OF NIGERIA AND THE GLOBAL ENVIRONMENT ARISING FROM OIL AND GAS EXTRACTIVE ACTIVITIES}

It is a well-known fact that air pollution in relationship with oil and gas extraction occurs, in different ways, which include: blowouts, geothermal steam and gas flaring. It is proposed to examine the different forms of air pollution in relation to oil and gas extractions in the form of blowout, geothermal steam along with the impact of gas flaring and its impacts on the atmosphere in the Niger Delta region in Nigeria, Africa and the world as a whole.

Blowouts refer to sudden and violent "escapes of gasses into the atmosphere". Such escapes occur when the pressure built around oil/gas wells become heavier than the wells' hydrostatic weights. ${ }^{4}$ The composition and character of the atmosphere is thereby altered to the detriment of the entire ecosystem including man. Yet, blowout is a very common feature associated drilling daily in the Niger Delta region of Nigeria. ${ }^{5}$ On the other hand geothermal steam refers to "the steam which is emitted into the atmosphere in the normal process of drilling. The steam so emitted consists of hydrogen sulphide, methane and ammonia. And on reaching the earth surface, the hydrogen sulphide is converted into sulphur dioxide with its attendant harmful effects on plants and animals including man. Amonia is known to combine with other compounds in the atmosphere in bringing about acidic rain. ${ }^{6}$

\footnotetext{
${ }^{1}$ See Environmental Legislation a Source Book (edited) by Mary Robinson Sive p. xxv.

${ }^{2}$ See Jesse Dukeminier, Jr., The Coming Search for Quality, (1964-65) 12 U.C.L.A. Rev. 707.

${ }^{3}$ Ibid.

${ }^{4}$ The sources discussed in this section are derived from D. Elsom, Atmospheric Pollution: A Global Problem, (2d ed. 1992) 369-70; M. Squillace, Environmental Law: Air Pollution (2d ed. 1992) 1-12; Urban Air Pollution in Megacities of the World, (WHO/UNEP Publication, Blackwell Publishers, London 1992), A. Wild, Soils and the Environment, (Cambridge, 1996) p. 211-232.

${ }^{5}$ Chemical Pollution, Earth and UNEP 1992 at p. 19.

${ }^{6} \mathrm{Ibid}$.
} 


\subsection{AIR POLLUTION IMPACTS AN ITS IMPACTS ON HUMAN LIFE AND THE ENVIRONMENT}

As alluded above, and as elaborated by Olanrewaju Fagbohun, in his authoritative text: The Law of Oil Pollution and Environmental Restoration (2010) ${ }^{1}$ (which views this authors totally adopts) and others, "the effect of air pollution is unseen but it can cause sudden devastation disaster to man and environment. The health effects of air pollution vary according to the intensity and duration of exposure and the health status of the population exposed. It has since being established that Carbon monoxide poses peculiar problems because it has a high affinity for haemoglobin and is able to displace oxygen and perhaps, most importantly, because oxygen transportations from the lungs to the tissue is severely impaired by $\mathrm{CO}_{2}$. This can result in cardiovascular and neurobehavioural effect carbon dioxide which acts as an asphixiant by reducing the amount of oxygen in the lungs by dilution. Althought, $\mathrm{CO}_{2}$ is a major natural consitituent of the atmosphere and is not considered a direct risk to health, yet, it has been discovered that chronic exposure to $\mathrm{CO}_{2}$ levels in excess of the predicted $600 \mathrm{ppm}$ by the year 2001, could adversly affect calcium metabolism."2 Air pollution, is further empirically established through findings to "adversely affect human health, not only by direct inhalation but also indirectly by other exposure routes, such as surface water contamination, food contaimination and skin transfer. Most ot the traditional air pollutants directly affect the respiratory and cardiovascular systems. Increased mortality, morbidity and impaired pulmonary function have been associated with elevated levels of $\mathrm{SO}_{2}$ and $\mathrm{SPM}$. Nitrogen dioxide and $\mathrm{O}^{3}$ also affect the respiratory system, acute exposure can cause inflammatory and permeability reactivity. The direct human health effects of air pollution vary according to both the intensity and the duration of exposure and also the health status of the population exposed". 3

In addition to the above, human health impacts asessments carried out in human environments as further validated by various studies shows that "a number of the pollutants considered have additional or indirect impacts on the environment. The sulphur and nitrogen oxides are the principal precursors of acidic deposition; long-rang transportation of $\mathrm{SO}_{2}, \mathrm{NO}_{\mathrm{X}}$ and their corresponding acidic transfomation products have been linked to soil and freshwater acidification with consequent adverse impacts on aquatic and terrestrial ecosystems. The growing pollution of the environment has led to a series of environmantally and health related problems in many of the urban cities in Niger Delta region and other parts of Nigeria as further shown in this paper below. Such health hazards are evident in the occurrence of respiratory diseases such as cough, bronchitis and lung cancers". ${ }^{4}$ According to a study undertaken by Uko and Banjoko, ${ }^{5}$ there are increases "in the carboxy-haemoglobin (cohhb) in the blood steams of about 60 patients upon whom the study was conducted higher than that permitted by health standerds. High level of carbonxyhaemoglobin in the body occurs as a result of inhaling carbon monoxide, which mixes with haemoglobin in the blood to form carboxy-haemoglobin. The implications of this high concentration of carboxy-haemoglobin on health include reduced exercise tolerance which translates into getting tired quickly during a light exercise, shortness of breath, fatigue, headache, among others". ${ }^{6}$

\subsection{EFFECTS OF AIR POLLUTION ON PLANTS, THE HUMAN ENVIRONMENT AND AIR SPACE} Many geseous pollutants have also being discovered to "inhibit plant growth and development. Pollutants may affect plants in several ways by the inhibition of th functional groups of plant enzymes, by overloading metabolic pathways for transforming or detoxifying pollutants, and thereby damaging the integrity of the plasma and cellular membranes. These processes may inhibit cellular productivity and also root growth and function, causing reduced ranslocation biomass production. The dose, the mixture of pollutants and the effects of other stresses such as pest, frost, drought, disease and acidification determine the sensitivity of plants to atmospheric pollutant. Also, air pollution is, known to dim visibility, city skylines and scenic beauty interferes with the safe operation of aircrafts and automobiles and disrupts transportation schedules"?

\subsection{FURTHER THOUGHTS ON GAS FLARING, ATMOSPHERIC POLLUTION, ITS IMPACTS AND STATUTORY INTERVENTIONS IN THE NIGER DELTA REGION OF NIGERIA}

We shall now proceed to considers gas flaring and its impacts specifically on the Niger Delta environments and the potency of statutory interventions in Nigeria. Gas flaring which is prominent though of devastating depletive effect in the environment is the process of burning unutilised associated gases into the atmosphere as is common with all our refineries. It was hoped that the hazards of gas flaring would be a thing of the past with the enactment of the Gas Re-injection Act 1979. The Act provided for the re-injection of unutilised associated gas back into the wells. The Act scheduled to end gas flaring in Nigeria on the $1^{\text {st }}$ of January, 1984 with its effective date which date

\footnotetext{
${ }^{1}$ See Olanrewaju Fagbohun, the Law of Oil Pollution and Environmental Restoration (2010) Published by Odade Polishers Comfort House (3 ${ }^{\text {rd }}$ Florr) 13, Hughes Avenue Alagomeji, Yaba Lagos State. Pp. 175-181.

${ }^{2}$ Chemical Pollution (op. cit.) p. 27.

${ }^{3}$ Ibid.

${ }^{4}$ For a semial work on air poolution, see UNEP and WHO, Urban Air Pollution of Megacities of the World, (Blackwell, 1992).

${ }^{5}$ See S. Akintoye, “Dying Gradually From Air Pollution”, Sunday Guardian, October 14, 1998.

${ }^{6}$ Ibid.

${ }^{7}$ See footnote 20 above.
} 
was later extended to $31^{\text {st }}$ of December 1987.

But unfortunately, on the $16^{\text {th }}$ of October, 1984, the Inspectorate Department of NNPC issued conditions under which gas flaring could be continued. These included:

i. where more than $75 \%$ of the produced gas is effectively utilised or conserved;

ii. where the gas contains more than $15 \%$ impurities such as Nitrogen, Hydrogen sulphide $\mathrm{H}_{2} \mathrm{~S}$, carbon dioxide $\mathrm{CO}_{2}$, etc., rendering the gas unsuitable for industrial use;

iii.when there is equipment failure provided such failures are infrequent and do not occur more than three times monthly;

iv.where it is not technically advisable to re-inject the gas in a particular field;

$\mathbf{v}$. if the company pays a fine of $2 \mathrm{k}$ per $28.317 \mathrm{scm}$ of gas flared in any field that does not meet the requirements above.

A cursory look at the conditions which have technically killed the Gas Re-injection Act, shows either the lack of awareness or non-appreciation of the enormity of the effects of gas flaring or lack of political will to tackle the issue. Oil companies thus find it much easier and convenient to continue gas flaring without taking into cognizance the damage being done to the environment. As alluded above, as "far back as the $1^{\text {st }}$ of January, 2008 a report showed that: "Nigeria flares about 2.4 billion cubic metres (0.84trillion cubic feet) of associated gas annually-the equivalent of $25 \%$ or $30 \%$ of the annual consumption of the US and EU, respectively" with an estimated annual loss of $\$ 2.5$ billion from gas flaring. ${ }^{2}$ On the $5^{\text {th }}$ of August, 2008 an official report made by the Federal Government of Nigeria was to the effect that "Nigeria losses N5.8billion daily to gas flaring". The said report noted that: "Nigeria is so blessed and so rich. Yet people are suffering, we are flaring gas and throwing it away as if it doesn't have meaning. We are losing approximately \$15million a day on flaring. When we are giving these people license why didn't we insist that there must be no flaring? Other countries have done it". ${ }^{3}$ It is perhaps necessary to note at this juncture that, gas flaring has being going on in Nigeria since 1958 and has gone on unabated till date and has contributed significantly to the release of "greenhouse gasses" into the atmosphere and not surprisingly to acid rain ${ }^{4}$ contributing to global warming. Gas flaring rose from 244.84 billion Standard Cubic Feet in 2016 to 287.59 billion in 2017 while gas flaring penalty stands at Nin/m SCF. Although the Government of the Federal Republic of Nigeria has increased the fines to be paid for gas flaring, it has also being observed, rightly in our view, that without the proper will and with the spirit of compromise everywhere we go here, nothing is likely to come out of this charade. That is reality. ${ }^{5}$ In the year 1993, Nigeria had established itself as a nation flaring more gas than any other nation in the world as shown in the table below. ${ }^{6}$

\footnotetext{
${ }^{1}$ The Guardian, January 1, 2008, p. 4

${ }^{2}$ Kiikpoye K.A. Op cit 272) See also Abila S.E: Impacts of Oil/Gas operations on the environment and summary of the legal regime governing the exploration and exploitation of oil mineral resources in Nigeria's Niger Delta (2018) the university of port Harcourt journal of private law, Vol. 3, Pp. 162-166.

${ }^{3}$ Ibid

${ }^{4}$ Osibanjo, O:Industrial Pollution Management in Nigeria; in: Aina, E.O.A and Ededipe, N.O. (eds): Environmental Consciousness for Nigerian National Development, Lagos, 1992, P. 97

${ }^{5}$ See The Guardian Editorial, Monday, October 8, 2018 page 16.

${ }^{6}$ (See Ibibia Lucky Woika, Environmental Law and Policy of Petroleum Development. (Strategy and Mechanism for Sustainable Management in Africa). Published by Anpez Centre for Environment and Development P.O. Box 106, Port Harcourt, Rives State P.45.

Result of (1) canal construction and canal widening, (2) road construction, (3) indirect impacts of charged hydrology, (4) areas covered with dredged soils. (5) activities in the Delta State. And most importantly, (6) activities of other oil companies, such as Mobil, Texaco, Agip, Elf, and Chevron just to mention these.) In 19889, it is reported that Nigeria flared off 613 billion cubic feet of associated gas and released in the process, about 30 million tons of $\mathrm{CO}_{2}$. In 994, the total estimated emission from Nigeria amounted to 35 million tons/year, and almost half of this is said to be $\mathrm{CO}_{4}$, the Nigerian contribution is even more considerable. Report 1, supra 86, p.58
} 
Table: Flaring of Natural Gas in Major Producing Countries. ${ }^{1}$

\begin{tabular}{|c|c|}
\hline \multirow{2}{*}{\multicolumn{2}{|c|}{$\begin{array}{lllll}\text { COUNTRIES } & \% & \text { OF } & \text { GROSS } & \text { GAS } \\
\text { PRODUCING IN 1991 } & \end{array}$}} \\
\hline & \\
\hline Nigeria & 76.0 \\
\hline Libya & 21.0 \\
\hline Saudi Arabia & 20.0 \\
\hline Iran & 19.0 \\
\hline Mexico & 5.0 \\
\hline United Kingdom & 4.3 \\
\hline Algeria & 4.0 \\
\hline United States & 0.6 \\
\hline Holland & 0.0 \\
\hline
\end{tabular}

Source: Escravos Staff Appraisal Report, 1993. Adapted from the Report 1, p. 59.

As highlighted earlier above, presently, complaints are rife in the Niger Delta Area of Nigeria that 'gas flaring has destroyed their plant and wildlife'. ${ }^{2}$ And a majority of the people of the Niger Delta 'have become half-deaf from the incessant din of the gas flare' ${ }^{3}$ A report has further confirmed the hazardous effect of gas flaring on human beings, plants and wildlife as follows: Gas flaring constitutes a veritable hazard. It causes acid rain which acidifies the lakes and streams and damages crops and vegetation. It reduces farm yields and harms human health, lives and livelihood; increases the risk of respiratory illnesses, asthma and cancer and often causes chronic bronchitis, decreased lung function, blindness, impotency, miscarriages and premature deaths. Gas flares have impoverished villages. The villagers have to live with the constant unnatural noise of the flare, and the area is covered in thick soot, making even rain water unsafe to drink. ${ }^{4}$

Only recently, two key stakeholders in change of petroleum and gas - Mr. Kachikwu and Dr. Maikanti Baru have both given different dates for the end of gas flaring, while Kachikwu has stuck to the 2019 date, Baru has said by 2020 all flaring must stop. This is tardy and confusing. ${ }^{5}$

0.8. EFFORTS MADE BY THE NIGERIAN GOVERNMENT TOWARDS CURBING AIR POLLUTION a. Nigeria's contributions to global greenhouse gas emission are high due to rapid population's growth and energy consumptions. To address this, the Federal Government has made a commitment to reduce Greenhouse gas emissions by $20 \%$ by 2030 .

b. In the past years, the government has introduced several initiatives to combat air pollution in the country. An example is the 2015 procurement and distribution of clean cooking stove, to reduce the inhalation of smoke that annually caused the death of about 90,000 women and also, to eliminate the felling of trees for firewood. Moreover, the government introduced the Green bonds, also known as climate bonds, as a fixed income securities issued to finance projects that have positive impact on the environment. The Bonds which is up to the tune of 150 million naira was created in 2016.

c. Another notable initiative was the creation of the Renewable Energy Programme by the Federal Ministry of Environment to ensure the reduction of gas emission into the environment. The major objective of the Renewable Energy Programme is to ensure that all sectors of the economy adopt cleaner sources of energy. Some of the on-going activities being carried out by the Renewable Energy Programme include:

i.The Rural Energy Women Empowerment Scheme (REWM) which was created to empower ten rural women cooperatives with the RUWES Business Model package-tricycle loaded with the cleaner energy lighting the cooking kits.

ii. The National Clean Cooking Scheme (NCCS), an aggressive drive to reduce and eventually eliminate cooking with firewood and kerosene. Under this scheme, the National Assembly intervention on clean cooking stoves initiative (NAICCI) was launched and has distributed clean cooking products across Kwara and Akwa Ibom States.

iii.The Rural Energy Access Project (REAP) was also created to ensure Rural Electrification. So far, it

\footnotetext{
${ }^{1}$ African producers are highlighted.

${ }^{2}$ See Human Rights Watch/Africa, Nigeria (1995) P. 8

${ }^{3}$ See Ikein op cit 269 citing Rowell, 'Shell Shocked: the Environmental and Social Costs of Living with Shell in Nigeria http://archieve.greenpeace.org/comms/ken/hell.html (last visited 26/10/05)

${ }^{4}$ The Guardian, Lagos, December 14, page 14

${ }^{5}$ See The Guardian Editorial, Monday, October 8, 2018 page 16.
} 
has provided and installed Stand Alone Solar System for 600 households in Taraba State. In addition, the World Bank in collaboration with the Government is currently supporting a raped bus system in Lagos that is aimed at reducing the number of cars on the road and to make transportation more efficient.

iv.Furthermore, the Nigerian government has recently pledged to improve environmental health by 2020 through a Pollution Management and Environmental Health Programme.

\section{CONCLUSION:}

This paper as considered observed challenges of air pollution in contemporary Nigerian and the global environment. The paper has attempted to isolate specific sources of air pollution, the dangers posed by the phenomenon. It also attempted to comparatively review incidences of air or atmospheric pollution in selected occurrences in Nigeria and other nations with a call for more proactive actions to deal with the menace of air pollution in the world.

\section{RECOMMENDATIONS:}

1. Efficient energy production involves increasing the use of renewable power sources. Like solar and wind, as well as encouraging the use of Liquefied Petroleum Gases instead of Firewood. Household and offices are also encouraged to make use of inverters and solar energy as opposed to generators which contribute a menace to air quality. Even though a cheap and readily available clean up method, burning of crop residues also known as bush burning, is very dangerous as a lot of smoke is released and inhalation has been associated with a larger risk of lung cancer, heart attack, lung disease, stroke and heart diseases. Local Farmers need to be educated by civil society and advocacy groups on these harmful effects to their health.

2. The Nigerian Government, despite its enormous positive contributions to ensuring a more habitable environment, needs to increase efforts at protecting public health by regulating the emissions of these harmful air pollutants. There is a need for proper regulation of environmental pollutions in Nigeria and Africa in general. Stringent rules are required to implement the safety standards that are already in place. Erring companies wrongly emitting greenhouse gases should be discouraged from doing so. A proper assessment of the sources of pollution at state levels is also very vital, which brings to fore the need for public and private sector investment in environmental research and development.

3. Business organizations also have vital roles to play in curbing air pollution. Industrial factories need to adopt more efficient ways of emitting gas waste as opposed to releasing it into the environment. These organizations can carry out their activities efficiently to prevent wastes as much as possible.

4. It is in the place of the public sector to establish a more efficient and effective transportation method, using new technology and clean energy to create effective, safe and cost friendly alternatives to the current mode of transportation, Nigeria can take a cue from India with respect to the imposition of tariffs on car owners. In a bid to reduce high level of air pollution caused by emissions from cars, the Indian Government imposed a $2.5 \%$ tax on cars that run on diesel and a $4 \%$ tax on SUVs and vehicles with bigger engines as opposed to a $1 \%$ tax levy on small cars.

5. Finally, construction and repair works on roads should be monitored so that the rate of emissions and deposition of particulate matter can be minimized whilst residents are protected from potential resultant health hazards. Distribution of masks to construction workers and residents as well as the adoption of land management techniques will as well, protect people from the dangers of dust storms.

6. As 2018 environment month runs to a close, many countries are pledging more commitments to investing in activities that can save the planet as well as impact on their society and economies, it behoves all economic, social and environmental actors in Nigeria to develop and effect strategies that will jointly strengthen the triple bottom lines of sustainability in the economic in the coming months and years.

7. The Lagos State Environmental Protection Agency (LASEPA) has a responsibility in this regard. In a densely populated metropolis like Lagos, deleterious fumes could build up or be accidentally released into the air unperceived. Only regular monitoring could detect the danger. It is not known how proactive the Lagos Air Quality Monitoring Study (LAQMS), initiated in 2007 has been. The agency should be diligent in performing its duties and should be able to pinpoint air pollution sources for abatement measures to be initiated. With urban solid wastes dumped all over the city, a lot of disease elements are floating and are being inhaled by the people. The drainage systems are overflowing with garbage. There is need for hygiene and this would require clear-cut approach from government as well as attitudinal change on the part of the people. Unfortunately, today, corruption has bastardised governance. There is no diligence in government. There is a complete break-down of cherished values and people now see nothing wrong in dumping refuse anywhere. Government should devise a strategy to maintain good environmental quality and the people should be carried along. A polluted environment means death to the people. The Lagos State Government should appreciate the fact that urban waste management is a major problem and it should act to make things better. 
8. As stated by the Guardian, Nigeria ${ }^{1}$ a threat by Minister of State for Petroleum Resources, Mr. Ibe Kachikwu that the government might revoke defaulting firms' licences has been met with scepticism. The reason is not farfetched. The government has never been able to summon the political will to enforce its own laws. The OICs prefer to pay the paltry fines in lieu of harnessing the gas resource. The harmful effects of gas flaring have been well documented. It has deleterious effects on nature including the depletion of the ozone layer. Farmlands can be negatively impacted, thus affecting the quantity and quality of farm yields. Besides, farmers cannot visit some of their farmlands because of extreme pollution. Aquatic or marine life is seriously threatened because of polluted waters, which endanger fish and other animals that depend on a healthy marine environment. The people who live in the areas where gas flaring takes place would readily tell you how easy it was for them to engage in fishing and harvest great catches before now. These days the fishes are becoming scarce. The rate of attrition is high and standard of living is also affected. Wildlife is also a victim of the same unhealthy condition. Plants and animals do not have enough light and darkness to assist production. Cassava and yam production has been severely reduced. What is worse, young people in these communities are permanently aggrieved. All of these have serious implications on the ecology of the land.

\footnotetext{
${ }^{1}$ See The Guardian Editorial, Monday, October 8, 2018 page 16.
} 